\title{
Çevrimiçi Alıșveriș Bağımlığı Ölçeğinin Türkçe Psikometrik Özelliklerinin İncelenmesi
}

\author{
Psychometric Properties of Turkish Online Shopping Addiction Scale
}

\author{
(1) Tuğba Yılmaz' ${ }^{1}$ (1) Gizem íkiz², (1) Furkan Mertcan Avcı² \\ ${ }^{1}$ Marmara Üniversitesi, Fen Edebiyat Fakültesi, Psikoloji Bölümü İstanbul, Türkiye \\ 2izmir Bakırçay Üniversitesi Fen Edebiyat Fakültesi, Psikoloji Bolumu İzmir, Türkiye
}

\section{Öz}

Amaç: Günümüzün en önemli problemlerinden biri olan çevrimiçi davranışsal bağımlılıklar araştırmacılar tarafından ölçülmeye çalışılmaktadır. İnsanların çevrimiçi alıșveriş yapma şekli ve tutumları da bu bağlamda araștırılmaktadır. Bu çalışmada çevrimiçci alışveriş bağımlılı̆̆ını ölçmek amacıyla geliştirilmiş olan bir ölçek olan Online Shopping Addiction Scale (OSA)'nın Türkçeye çeviri, uyarlanma ve geçerlik ve güvenirlik çalışmalarının yapılması amaçlanmıştır.

Yöntem: Bu çalıșma süresince bir ay ara ile iki farklı zaman diliminde ölçüm gerçekleștirilmiștir. illk olarak 324 katılımcıya Çevrimiçi Alıșveriş Bağımlılığı Ölçeği (ÇABÖ), Kompulsif Çevrimiçi Satın Alma Ölçeği ve Young İnternet Bağımlılı̆̆ı Ölçeği-Kısa Form uygulanmıştır. İkinci ölçümde ise ilk ölçümlere katılan 110 katılımcıya Çevrimiçi Alışveriş Bağımlılı̆̆ı Ölçeği uygulanmıştır.

Bulgular: Orijinalinde altı faktörlü bir ölçek olan ÇABÖ’nün Türkçe uyarlamasının ilk iki faktörün (belirginlik ve tolerans) birleşmesiyle beş faktörde toplandığı bulunmuştur. Ölçeğin iç tutarlık katsayısı .92, test tekrar-test güvenirliği .79 olarak bulunmuştır. Ölçeğin beş alt faktörünün iç tutarlık katsayılarının .40-.88 arasında değiştiği bulunmuştur. ÇABÖ’nün eş geçerliliği Young İnternet Bağımlılığı Ölçeği Kısa Form ve Kompulsif Çevrimiçi Satın Alma Ölçeği ile test edilmiş ve anlamlı sonuçlar elde edilmiştir.

Sonuç: Araştırmanın sonuçları Çevrimiçi Alışveriş Bağımlılığı Türkçe uyarlamasının geçerli ve güvenilir olduğunu göstermektedir.

Anahtar kelimeler: İnternet bağımlılığı, bağımlılık davranışları, kompülsif davranış

\section{Abstract}

Objective: Online behavioral addictions, one of the most important problems of today, are tried to be measured by researchers. The way people shop online and their attitudes are also explored in this context. In this study, it is aimed to carry out the Turkish translation, adaptation, validity and reliability studies of the Online Shopping Addiction Scale (OSAS), a scale developed to measure online shopping addiction.

Method: During this study, measurements were carried out in two different time periods with a one-month interval. First of all, Online Shopping Addiction Scale (OSAS), Compulsive Online Buying Scale and Young Internet Addiction Scale-Short Form were applied to 324 participants. In the second measurement, the Online Shopping Addiction Scale was applied to 110 participants who participated in the first measurements.

Results: It was found that the Turkish version of the CABÖ, which was originally a six-factor scale, gathered in five factors by combining the first two factors (significance and tolerance). The internal consistency coefficient of the scale was found to be .92, and the test-retest reliability was found to be .79. It was found that the internal consistency coefficients of the five sub-factors of the scale ranged from .40 to .88. The concurrent validity of the OSAS was tested with the Young Internet Addiction Scale, the Short Form, and the Compulsive Online Buying Scale, and significant results were obtained.

Conclusion: The results of the study show that the Turkish version of Online Shopping Addiction Scale is valid and reliable.

Keywords: Internet addiction, addictive behavior, compulsive behavior 


\section{Giriş}

Internet, dijital çă̆ olarak da anılan günümüz dünyasında yaşam biçimlerini şekillendirmekte rol oynayan en önemli faktörlerden biridir. İnternetin hızla değișen yapısına paralel olarak insanların alıșveriş yapma șekli ve alıșveriş yapmaya dair tutumları da teknolojik dönüşümlere, zamana ve birtakım demografik değişkenlere bağıı olarak değişim göstermektedir (1). Artık müșteriler fiziksel olarak mağazaya gidip alıșveriș yapmak zorunda kalmadan internet üzerinden alışveriş yapabilmektedir. Çevrimiçi alıșveriş, e-alışveriş, internet üzerinden alıșveriş ya da web tabanlı alışveriş olarak adlandırılabilen bu alışveriş biçiminin insanların günlük yaşamlarını büyük ölçüde değiştirmesi beklenmektedir (2).

Ülkemizde 2021 yılında evden internete ulașım imkânı \%92 olarak belirtilmiștir. Neredeyse her evden ulașılabilir bir hale gelen internete paralel bir biçimde çevrimiçi alışveriş oranı da gitgide yükselmektedir. Türkiye İstatistik Kurumu tarafından her yıl yapılmakta olan Hanehalkı Bilişim Teknolojileri araşıırmasının 2021 yılı sonuçlarına göre çevrimiçi bir biçimde ürün sipariş eden ya da çevrimiçi hizmet talep eden bireylerin oranı \%44,3 olarak belirlenmiştir, aynı oran önceki yıl \%36,5 olarak kayıtlara geçmiștir. Çevrimiçi alıșveriş yapan bireylerin \%70,7'si giyim, ayakkabı ya da aksesuar alışveriși yaparken, \%40,8'i çevrimiçi yemek siparişi ya da catering hizmeti talep etmiştir. \%27,7'si kitap, dergi ya da gazete alışverişi yaparken. \%27,6 oranında temizlik ve kişisel bakım ürünleri alışverişi yapılmıştır (3). Ülkemizde çevrimiçi alışveriş pazar büyüklüğü de her geçen yıl hızla artmaktadır. 2018 yılında 59,9 milyar Türk Lirası olarak belirtilmiş olan e-ticaret hacmi 2019 yılında \%39 oranında bir büyüme göstererek 83,1 milyar Türk Lirasına ulașmıștır (4). Bunların yanı sıra 2020 yılında dünyayı büyük ölçüde etkileyen Covid-19 Pandemisinin de çevrimiçi alışveriş yapma davranışını arttırdığı gözlenmiștir (5).

Çevrimiçci alışveriş yaygınlaştıkça bireyler tarafından nasıl algılandığı da merak edilen bir konu halini almıștır. Algür ve Cengiz (6) tarafından yapılan ve çevrimiçi alışverișe dair algılanan risk ve avantajların incelendiği bir araștırmada bireyler tarafından algılanan en önemli avantajlar var olan ürün çeşitliliği ve zamandan tasarruf edilmesi olarak ifade edilmiștir. Kimlik ve kredi kartı bilgilerinin paylaşılmasına dair duyulan endișe ise bireyler tarafından algılanan önemli riskler olarak belirtilmiștir. Bunların yanı sıra çevrimiçi alışveriş yapma davranışının çeşitli demografik özellikler tarafından etkilendiği de bilinmektedir. Örneğin, Akther (7) tarafından yapılan çalışmada erkeklerin kadınlardan, gençlerin yaşlılardan daha fazla çevrimiçi alışveriş yaptığı belirtilmiștir. Şeker (1) tarafından kültürümüzde yapılan bir çalışmada ise kadın ve erkeklerin çevrimiçi alışveriş yapma davranışlarında anlamlı bir farklııık bulunmazken, yaș değișkeni bağlamında incelendiğinde ise daha genç tüketicilerin 46 yaş ve üzerindeki tüketicilere kıyasla daha fazla çevrimiçi alıșveriş yaptığı belirlenmiștir. Bununla birlikte eğitim ve gelir düzeyinin artması da çevrimiçi alışveriş yapma davranışını arttırmaktadır. Bunun yanı sıra eğitim düzeyi yükseldikçe çevrimiçi alışveriş yapma davranıșının arttığı, ancak gelir düzeyi ya da medeni durumun çevrimiçi alışveriş yapma davranışına herhangi bir etkisi olmadığı ifade edilmiștir.

Davranışsal bağımlılıklar, herhangi bir madde kullanımı olmaksızın davranış üzerindeki kontrolün azalması, yoksunluk ve tolerans (dayanıklılı) gibi madde kullanım bozukluklarındaki belirtileri içerir. Kontrolün azalması aynı zamanda madde bağımlılığını tanımlayan temel kavramlardan biri olduğu için davranışsal bağımlılık kavramı madde bağımlııı̆ı kavramıyla benzerlik göstermektedir (8). Çevrimiçi alışveriş bağımlılığı yapısı gereği davranışsal bir bağımlılık olarak ele alınabilir. Çevrimiçi alışveriș bağımlılığı bireyin sosyal hayatı ve günlük yaşamının yanı sıra ekonomik durumu üzerinde de olumsuz etkiler yaratabilir (9). Bu yüzden çevrimiçi alıșveriş bağımlıığının teșhisi, müdahalesi ve tedavisi büyük bir önem taşımaktadır (10). Bu noktada çevrimiçi alışveriş bağımlıı̆ı̆ını yordayıcı bazı faktörlerden söz etmek yararlı olacaktır.

Rose ve Dyandayudham (9) tarafından yapılan bir araştırmada çevrimiçi alıșveriş bağımlılığını yordayıcı 7 faktör önerilmiștir. Düşük benlik saygısı çevrimiçi alıșveriş bağımlılığını doğrudan yordayan bir faktör olarak önerilmiștir. Bunun yanı sıra düşük öz-düzenleme, olumsuz duygusal durum ve çevrimiçi alışveriş yaparken alınan haz faktörlerinin de çevrimiçi alışveriş bağımlılığı geliștirmede kilit bir rol oynayabileceği ifade edilmektedir. Önerilen diğer bir faktör de cinsiyet bağlamında ele alınmış, kadın olmanın çevrimiçi alışveriş bağımlılığı geliştirilmesi konusunda yordayıcı bir rol oynayabileceği belirtilmiştir. Son olarak, sosyal anonimlik ve bilişsel aşırı yüklemenin çevrimiçi alışverişi olumlu etkilediği görülmektedir. Sosyal anonimlik, diğer müşterilerin ya da satıcıların tepkilerine maruz kalmayı önlemesi sebebiyle çevrimiçi alışverişi teșvik etmektedir. Çevrimiçi alışveriş web sitelerindeki görseller, animasyonlar, açilır pencere uygulamaları (pop-up) ve bildirimler de kişileri bilişsel aşırı yüklemeye maruz bırakmakta, kendilerini kontrol etme becerilerini zayıflatmakta ve bu da çevrimiçi alışverişin artmasının önünü açmaktadır (9).

Çevrimiçi alıșveriș ile ilgili yapılan çalıșmalarda kişiliğe yapılan vurgu dikkati çekmektedir. Kișilik özelliklerini beș-faktör kişilik kuramı (deneyime açıklık, sorumluluk, dışa dönüklük, uyumluluk ve duygusal dengesizlik) ile ölçen bu çalışmalar, çevrimiçi alışveriş yapma motivasyonlarının üzerindeki etkileri ile kişiliği ele almıștır. Huang ve Yang (11) çalıșmasında deneyime açıklık kişilik özelliğinin çevrimiçi alışverişte yeni macera ve fikirlerle karşılaşma motivasyonları; sorumluluk kişilik özelliğinin çevrimiçi alışverişin kolaylığı motivasyonu; dışadönüklüğün çevrimiçi alışverişin sosyalleşme motivasyonu ve duygusal dengesizliğin ise çevrimiçi alışverişin sosyal anonimlik motivasyonu ile ilișkili olduğuna ișaret etmiștir. Tsao 
ve Chang (12) ise duygusal dengesizlik, deneyime açıklık ve dışadönüklük kişilik özelliklerin çevrimiçi hazza dayalı alımla ilgili olduğunu belirtmiștir. Kișilik özelliklerinin gerçekleștirilmiş çevrimiçi alışverişteki rolünün incelenmesine intiyaç duyulduğu görülmektedir.

Alanyazında çevrimiçci alışveriş bağımlılığı risk faktörlerini konu alan çalışmalar saptanmamıştır; ancak çevrimiçi alışveriş bağımlılığının kompulsif satın alma davranıșı ve internet bağımlılı̆ı ile yakın ilişkide olduğu incelenmiștir. Bu nedenle, internet bağımlılığı ve kompulsif satın alma davranıșının komorbiditelerini incelemek faydalı olacaktır; çünkü iki bozukluğun komorbiditesi nedensel bir ilișkiyi veya ortak bir etiyolojiyi gösterebileceği düşünülmektedir (13).

Araştırmacılar çevrimiçi alışveriş bağımlılığının internet bağımlılı̆̆ı kategorisinde sınıflandırılabileceğini belirtilmektedir $(14,15)$. Kuss ve arkadașları (16), internet kullanımıyla ilgili olarak, çevrimiçi alışverişin, internet bağımlıı̆̆ının önemli bir belirtisi olduğunu ve çevrimiçi alışveriște birim artışın internet bağımlısı olma olasılığını \%135 artırdığını; internet bağımlısı olmanın çevrimiçi alıșveriși artırdığını bulgulamıștır. Bu noktada internet bağımlılığııın tanımlanması ve diğer bozukluklarla ilişkisini incelemek faydalı olacaktır.

Internet bağımlılığı, bağımlı kişinin aile, iş, sosyal vb. hayatının da bu durumdan etkilendiği; önüne geçilemeyecek derecede internette aşırı zaman geçirme isteği, yoksunluk durumunda meydana gelen saldırganlık ve sinirlilik durumu şeklinde tanımlanabilmektedir (17). Yetişkinlerde DEHB'nin, internet bağımlılığı için önemli belirleyicisi olmasının yanında depresif bozukluklar ve kişisel internet kullanımı yüksek ölçüde ilişkilidir $(18,19)$. Diğer bir önemli nokta, internet bağımlısı olan kișilerde dürtü kontrolü ve bağımlılık yapıcı bozuklukların komorbid olmasıdır; bu bozukluklara sahip olan bireyler, problemli internet kullanımı riski altındadır (20,21). Internet ortamı; kumar bağımlılarının, alıșveriș bağımlılarının, seks bağımlılarının ve bilgisayar bağımlılarının hastalıklarını sergilediği farkı bir alan sunmaktadır (22). Ayrıca, komorbidite olan internet bağımlılığı, özellikle obsesif-kompulsif semptomlar ve kişilerarası duyarlııı gibi psikososyal belirtilerle ilişkilendirilmiştir (23).

Kompulsif satın alma, tüketicinin tekrarlayan satın alma ve satın alma üzerinde dürtü kontrolünün gerçekleșmemesiyle ortaya çıkan satın almayla meşgul olma eğilimi olarak tanımlanmaktadır (24); patolojik satın alma (PB), kompulsif satın alma, satın alma bağımlııı̆ı ve oniomania bu kavramı tanımlayan farklı terminolojilerdir (25). Çevrimiçi alışveriş bağımlılı̆ı ve kompulsif satın alma, özellikleri yönüyle oldukça benzer olsa da internet sınırlamasında aralarında farklılıklar bulunmaktadır; çevrimiçi alışveriş bağımlıı̆̆ının internet ile sınırlıyken kompulsif satın almada böyle bir sınır yoktur (10). Kompülsif satın alma; depresyon, obsesif-kompulsif bozukluk, yeme bozuklukları, alkol ve nikotin bağımlılığı ve dürtü kontrol bozuklukları (aralıklı patlayıcı bozukluk, kleptomani, piromani, patolojik kumar, trikotilomani) gibi çeșitli komorbid psikiyatrik bozukluklarla ilişkilendirilmiştir $(26,27)$. Kompulsif satın almanın nedenlerine yönelik yapılmış olan biyokimyasal araştırmalarda, serotonindeki dengesizliklere odaklanıldığı, kompulsif satın almayı etkileyen psikolojik faktörlerin, düşük benlik saygısı, depresyon ve anksiyete olduğu belirtilmektedir (28).

Zhao ve arkadașları (10) tarafından geliștirilmiş; çalıșmamızda da çeviri ve uyarlaması gerçekleştirilmiş olan Çevrimiçi Alışveriş Bağımlılığı Ölçeği (Online Shopping Addiction Scale) dıșında çevrimiçi alışveriş bağımlılı̆̆ının ölçülmesi için kullanılabilecek ölçekler yer almaktadır. Bunlardan biri olan Bergen Alışveriş Bağımlılığı Ölçeği, maddelerin içeriğiyle alışveriş alıșkanlıklarını yansıtan ve iyi bir geçerlilik ve güvenilirliğe sahip; alıșveriş bağımlılığının temel kriterlerini ve bileșenlerini ölçmek için tasarlanmış bir ölçektir (29). Ölçek, Ruhsal Bozuklukların Tanısal ve Sayımsal El Kitabı'nda (DSM-IV-TR; 30) listelenen yedi bağımlılık ölçütünün her biri için dörder olmak üzere 28 maddeden oluşmaktadır. Bunun yanı sıra Bergen Alışveriş Bağımlılığı Ölçeği'nin çevrimiçi alıșverişlere uyarlanarak geliștirilen bir versiyonu olan Kompulsif Çevrimiçi Satın Alma Ölçeği (KÇSA), kompulsif çevrimiçi satın alma bozukluğunun ölçümü ve değerlendirmesinde kullanılabilecek, psikometrik özelliklerinin güçlü olduğu belirlenen bir ölçektir (31). Ayrıca, Kompulsif Çevimiçi Alışveriş Ölçeği, Andreassen ve arkadașlarının (29) elde etmiş olduğu sonuçlarla uyumlu olarak güçlü psikometrik ve yapısal göstermektedir (32). İlgili bir diğer ölçek, internet bağımlılığı olarak çevrimiçi alıșveriş bağımlıı̆ğını inceleyen araştırmacılar tarafından kullanılmıștır. Çevrimiçi alışveriş bağımlılığının ölçümü için, kısa PROMIS anketinin (33) on maddelik alt ölçeğinde "internet veya çevrimiçi” kelimelerinin değiștirilmesiyle güvenilir olduğu belirtilmiștir (34). Ayrıca Dikbaş ve arkadașları (35) tarafından Türkçe'ye uyarlama çalıșması gerçekleștirilmiş olan Pathological Buying Screener (36), bu konuyla ilișkili olarak Türk kültüründe kullanılabilecek güncel bir ölçek olarak karșımıza çıkmaktadır.

Çevrimiçi alışveriş bağımlıı̆̆ bireyin ekonomik durumu, günlük yaşamı ve sosyal hayatı üzerinde olumsuz etkilere sahiptir. Türkçe alanyazın incelendiğinde Bozdağ ve Yalçınkaya-Alkar'ın (31) geliștirdiği Kompulsif Çevrimiçi Satın Alma Ölçeği'nde, Bergen Alışveriş Bağımlılığı Ölçeği'nin kompülsif çevrimiçi satın alma davranışına uyarlandığı görülmektedir. Ancak doğrudan çevrimiçi alışveriş bağımlılığını ölçümlemek adına geliştirilmiş ya da uyarlanmıș bir ölçeğin bulunmadığı görülmüștür. Bu intiyaç doğrultusunda geçerli ve güvenilir bir ölçek geliștirmek veya uyarlamak gerekmektedir. Bu çalıșmanın amacı, çevrimiçi alıșveriş bağımlılığı kavramını tanımlamak ve kültürümüzde kullanılabilecek geçerli ve güvenilir bir ölçüm aracı olușturmak amacıyla Çevrimiçi Alışveriş Bağımlılığı Ölçeği'ni (Online Shopping Addiction Scale) Türkçe'ye uyarlamaktır (10). 


\section{Yöntem}

\section{Örneklem}

Örneklemin oluşturulmasında \%80 istatistiksel güç ve $\alpha=0.05$ anlamlılık düzeyinde, doğrulayıcı faktör analizi için $d=0.50$ etki büyüklüğünü tespit etmek için gereken en küçük örneklem genișliği 74 olarak hesaplanmıștır. Bu bilgiden hareketle, çalışmanın örneklemi İzmir Bakırçay Üniversitesi Psikoloji Bölümü öğrencileri ve sosyal medya platformları üzerinden kartopu örnekleme yöntemiyle ulașılan 249 kadın (\%76.9) ve 75 erkek (\%23.1) olmak üzere 324 katılımcı olușturmaktadır. Katılımcıların 287'si bekar (\%88.6) 37'si evli (\%11.4); yașları 18$62(\mathrm{M}=24.07, \mathrm{SD}=6.42)$ aralığındadır. 175 katıımının (\%54.0) en son mezun olduğu okul lise, 124 katılımcının (\%38.3) lisans, 25 katılımcının (\%7.7) ise lisansüstü düzeydir. Katılımcıların \%45.7'nin gelir düzeyi 1000 TL'den az, \%20.7'sinin 1001-3000 TL, \%12.7'sinin 3001-5000 TL, \%10.5'inin 5001-7000, \%6.8'inin 70019000 TL ve \%3.7'sinin 9000 TL ve üzeridir. Katılımcıların tamamı çevrimiçi alışveriş yaptığını bildirmiştir, herhangi bir katılımcının verisi dışlanmamıştır. İnternetten alışveriş yapmak ve 18 yaşından büyük olmak çalışmanın dahil edilme kriterleridir.

\section{İşlem}

Online Shopping Addiction Scale orijinal adı ile İngilizce dilinde geliștirilmiș olan bu ölçeğin yazarlarından Tao Xin'e e-mail yolu ile ulaşılarak ölçeğin Türkçe'ye kazandırılması için izin alınmış̧ır. Çalışmanın gerçekleştirilebilmesi için gerekli etik kurul izni, 17.03.2021 tarihinde İzmir Bakırçay Üniversitesi Etik Kurulu'ndan alınmıștır (Karar No:209, Araștırma No:191). Veriler çevrimiçi ortamda, gönüllülük esasına dayalı, anonim olarak toplanmış ve katılımcılara ölçekler Google formlar aracılığıyla ulaștırılmıștır. Veriler toplanmaya bașlamadan önce 22 kişiye pilot uygulama yapılmış ve maddelerin anlașılırlığı hakkında geribildirimler alınmışır. İzmir Bakırçay Üniversitesi Psikoloji bölümü öğrencilerine bonus puan teșviği sağlanmıștır. Araștırmaya katılım yaklaşık 10 dakika sürmüștür. Araștırma kapsamında katılımcıların psikolojik değerlendirmelerinin yapıldığı herhangi bir görüșme gerçekleștirilmemiștir.

Katılımcılara ilk olarak aydınlatılmış onam formu sunulmuş, katılımcılar çalıșma hakkında bilgilendirilmiş̦tir. Sonrasında Çevrimiçi Alışveriş Bağımlılı̆̆ı Ölçeği katılımcılara sunulmuștur. Eş zamanlı geçerlilik için ise Kompülsif Çevrimiçi Satın Alma Ölçeği (KÇSA) ve Young İnternet Bağımlılığı Ölcçeği-Kısa Form (YiBT-KF). Test-tekrar test ölçümleri için katılımcılarla bir ay ara ile tekrar iletişim kurulmuştur.

Ölçek maddeleri İngilizce ve Türkçe dillerine hâkim psikologlar tarafından çeviri geriçeviri yöntemi çevrilmiștir (39). Ingilizce'den Türkçe'ye yapılan çeviriler karșılaştırılmış, farklı çevrilmiş maddeler belirlenmiş ve uygun çevirinin bulunması sağlanmıștır. Maddelerin hazırlanması sonrası, İngilizce ve Türkçe dilinde yetkin farklı mesleklerden iki kiși tarafından maddeler İngilizce'ye çevrilmiş ve orijinal maddelerle kıyaslanmıştır. İlk ölçümlere katılan 324 katılımcılan 110'u ikinci ölçümlere katılmıștır.

\section{Veri Toplama Araçları}

\section{Demografik Bilgi Formu}

Bu form ile katıımcıların yaşları, cinsiyetleri, medeni durumları, eğitim ve gelir düzeyleri, internet kullanım alıșkanlıkları (kaç yıldır internet kullanıldığı ve internette günlük kaç saat geçirildiği) ve çevrimiçi alıșveriș yapma durumları (çevrimiçi alıșveriş yapılıp yapılmadığı, hangi sıklıkla yapıldığı, katılımcıların ihtiyaçlarını çevrimiçi yöntemlerle mi mağaza ortamında mı giderdiği, çevrimiçi alışveriş için bankadan kredi çekilip çekilmediği ve çevrimiçi alışveriş için çevreden borç alınıp alınmadığı) hakkında sorular sorulmuştur.

\section{Çevrimiçi Alışveriş Bağımlılığı Ölçeği (ÇABÖ)}

Orijinal dili İngilizce olan ve Zhao ve arkadaşları (10) tarafından geliştirilmiş Çevrimiçi Alışveriş Bağımlılığı Ölçeği (Online Shopping Addiction Scale); belirginlik $(\alpha=.76)$, tolerans ( $\alpha=.84)$, duygudurum değişikliği $(\alpha=.71$ ), yoksunluk ( $\alpha=.83$ ), nüksetme ( $\alpha=.84$ ), çatışma ( $\alpha=.83$ ) olarak 6 faktör ve her faktörde yer alan 3 madde ile toplam 18 maddeden olușmaktadır. САВÖ 5'li likert skalası (1=Tamamen katılmıyorum, 5=Tamamen katılıyorum) üzerinde cevaplanmaktadır. Ölçeğin orijinalinde iç tutarlılık katsayısı $\alpha=.95$ olarak belirtilmiștir. Uyarlanmış ölçekte ise ölçeğin tamamının iç tutarlılık katsayısı $\alpha=.923$ olarak bulunmuştur. Alt ölçekler, belirginlik-tolerans $(\alpha=$ .869), duygudurum değişimi ( $\alpha=.884)$, yoksunluk ( $\alpha=.785)$, nüks etme $(\alpha=.822)$ ve çatışma $(\alpha=.403)$ şeklinde iç tutarlıık değerleri göstermiş̧tir. Ölçek Türkçe'ye yazarlar tarafından çevrilmiştir.

\section{Young İnternet Bağımlılığı Ölçeği-Kısa Form (YIBT-KF)}

Young (37) tarafından internet bağımlılık belirtilerinin ölçülmesi için geliștirilmiş ve Kutlu ve arkadașları (38) tarafından Türkçe'ye uyarlanan Young Internet Bağımlılığı Ölçeği-Kısa Form (YỉBT$\mathrm{KF})$, tek boyut ve 12 maddeden oluşmaktadır ve beşli Likert (1=Hiçbir zaman, $5=$ =Çok sık) tipi bir ölçektir. Kutlu ve arkadaşları (38) tarafından ölçeğin iç tutarlık güvenilirlik katsayısı .85 olarak hesaplanmıștır. Ölçekten alınabilecek puan 12 ile 60 arasında değişmektedir ve ölçekten alınan yüksek puanlar internet bağımlılığı düzeyinin yüksek olduğunu göstermektedir. Ölçekte ters madde bulunmamaktadır. (38)

\section{Kompulsif Çevrimiçi Satın Alma ÖIçeği (KÇSA)}

Andreassen ve arkadaşları tarafından 2016 yılında geliştirilmiş olan Bergen Alışveriş Bağımlılı̆̆ Ölçeği'nin hem çevrimiçi bağlama hem de Türkçeye uyarlanması Bozdağ ve YalçınkayaAlkar (31) tarafından gerçekleștirilmiștir. Ölçeğin orijinal maddelerine çevrimiçi ibaresini eklenerek çevrimiçi kompulsif 
alışveriş davranışının ölçülmesinin amaçlandığı bu ölçekte toplam 28 madde bulunmaktadır. Ölçeğin orijinal formunda .87 olarak hesaplanan cronbach alfa iç tutarlıık katsayısı, uyarlama formda .95 olarak hesaplanmıştır. 5’li Likert (0 -Tamamen Katılmıyorum, 4- Tamamen Katılıyorum) tipinde olan ölçek, Problem-çatışma-nüks ( $\alpha=$.95), düşünce ile meşgul olma ( $\alpha$ $=.78)$, duygu düzenleme ( $\alpha=.93)$, geri çekilme $(\alpha=.87)$ ve tolerans $(\alpha=.90)$ olmak üzere 5 alt ölçekten oluşmaktadır. Ölçekten yüksek puan alınması bireylerin çevrimiçi kompulsif alıșveriş bozukluğu düzeyinin arttığına işaret etmektedir. Ölçekten alınabilen en düşük puan 0, en yüksek puan ise 112 olarak belirlenmiștir. (31).

\section{Veri Analizi}

Çalışma çevrim içi platformlarda gerçekleștirilmiștir bu nedenle ölçeğin kısmi doldurulma durumu söz konusu olmamıștır. Dolayısı ile eksik ya da kısmi doldurma nedeni ile katıımcı silme ișlemi yapılmamıştır. Çalıșmada elde edilen verilerin istatiksel analizleri SPSS ve JAMOVI paket programları ile yapılmıştır. Öncelikle parametrik testlerin kullanılıp kullanılamayacă̆ını anlamak adına değişkenlerin normallikleri değerlendirilmiștir. Değişkenlerin basıklık ve çarpıklık değerleri +2 ve -2 arasında olduğunda değişkenin normal dağıldığı kabul edilmiștir (40).
Çevrimiçi Alışveriş Bağımlılığı Ölçeği (ÇABÖ)'nin faktör yapısının orijinal ölçekteki gibi 6 alt ölçekli/faktörlü olup olmadığının saptanması için doğrulayıı faktör analizi yapılmıştır. Çevrimiçi Alışveriş Bağımlılığı Ölçeği iç tutarlılık düzeyi Cronbach's alfa katsayıları ile belirlenmiștir. Illk toplanan veriler ve ikinci toplanan veriler arasında güvenirlik analizi için Pearson korelasyon analizi yapılmıştır. Yapı geçerliği, ÇABÖ'den elde edilen veriler, Young Internet Bağımlıı̆̆ı Ölçeği-Kısa Form (YiBT-KF) ve Kompulsif Çevrimiçi Satın Alma Ölçeği (KÇSA)'nden elde edilmiş olan verilerle korelasyon analizi yapılarak ölçülmüștür.

\section{Bulgular}

\section{Ölçeğin Faktör Yapısı}

324 katılımcıdan elde edilen verilerle doğrulayıcı faktör analizi yapılmıștır. Kaiser-Meyer-Olkin (KMO) Katsayısı ve Barlett Küresellik Testi verilerin faktör analizine uygunluğunun test edilmesi için yapılmıştır; KMO değeri (.92) ve Barlett's Testi sonucu $\left(X^{2}=3248.67, \mathrm{df}=153, \mathrm{p}<.001\right)$ elde edilen verilerin temel bileșen analizi için uygun olduğu saptanmıștır. Analizde en uygun faktör yapısını belirleyebilmek adına farklı faktör sayıları denenmiştir ve Tablo 1'de görüldüğü üzere, ölçeğin en uygun olarak orijinalinden farklı olarak ilk iki faktör olan belirginlik

Tablo 1: Alt faktörler ve maddelere göre faktör yükleri

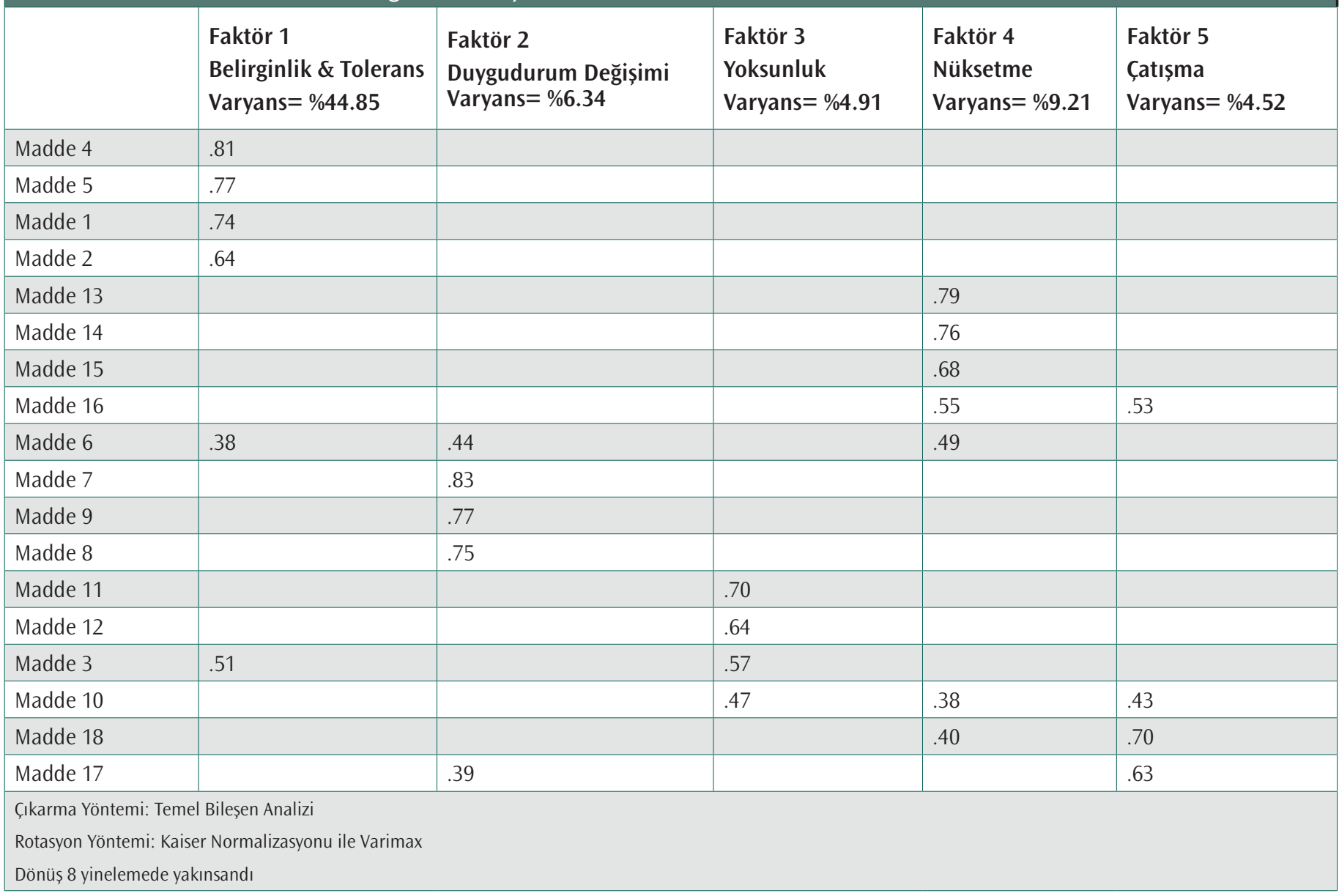


ve tolerans faktörlerinin birleșmesiyle beș faktörde toplandığı bulunmuștur. Çevrimiçi Alışveriş Bağımlılığı Ölçeği'nin beş faktörlü halinin uyum indeksleri doğrulayıc faktör analizi ile incelenmiş̦tir SB $\chi 2=405, \mathrm{df}=125, \mathrm{p}<.001, \mathrm{CFI}=.912$, RMSEA $=.0831, \mathrm{TLI}=0.892$.

\section{Alt ÖIçekler Arası Korelasyonlar}

Çevrimiçi Alıșveriş Bağımlılığı Ölçeği (ÇABÖ)'nin Belirginlik ve Tolerans, Duygudurum Değişimi, Yoksunluk, Nüks, Çatışma bașlıklarına sahip beș alt ölçeği arasındaki ilișkiler Tablo 2'de gösterilmiștir. Tüm alt ölçekler birbirleriyle $p<.01$ düzeyinde istatistiksel olarak anlamlı korelasyon göstermiștir. En güçlü korelasyon .65 ile Belirginlik ve Tolerans alt ölçeğinin duygudurum değişimi altölçeği ve yoksunluk altölçeği ile arasında, en zayıf korelasyon Duygudurum Değişimi ve Çatışma alt ölçekleri arasında bulunmuştur.

\section{Güvenirlik Göstergeleri}

ÇABÖ'nün test-tekrar test güvenirliğini incelemek için katılımcılara ilk katılımlarından bir ay sonra ikinci uygulama için ölçek gönderilmiş, 110 katılımcıya ulaşılmış ve bu katılımcılar üzerinden iki uygulama arasındaki korelasyon hesaplanmıștır. Yapılan korelasyon analizi neticesinde $r=.79, p<.01$ seviyesinde anlamlı șekilde bulunmuștur.

ÇABÖ'nün iç tutarlılığı Cronbach's Alpha katsayıları incelenerek belirlenmiştir. Buna göre ölçeğin tamamının iç tutarlılık değeri $\alpha=.923$ olarak bulunmuștur. Belirginlik-Tolerans alt ölçeği $\alpha$ $=.869$, duygudurum değişimi alt ölçeği $\alpha=.884$, yoksunluk alt ölçeği $\alpha=.785$, nüks etme alt ölçeği $\alpha=.822$ ve çatışma alt ölçeği $\alpha=.403$ şeklinde iç tutarlılık değerleri göstermiștir.

ÇABÖ'deki 18 maddenin ortalama, standart sapma değerleri gibi merkezi eğilim göstergeleri, düzeltilmiş madde-bütün korelasyonu ve madde silindiğindeki güvenirlik değerleri ile birlikte Tablo 3'te gösterilmektedir. Ayrıca bu tabloda alt ölçeklerde hangi maddelerin bulunduğu bilgisi de yer almaktadır.

\section{Yapı Geçerliği}

ÇABÖ'nün yapısal geçerliliğini değerlendirmek amacıyla YiBT-KF ve KÇSA ölçüm araçları kullanılmıştır. Young İnternet Bağımlıı̆̆ı
Ölçeği - Kısa Form tek boyuttan oluşmaktadır. KÇSA problemçatışma-nüks, düşünce ile meşgul olma, duygu düzenleme, geri çekilme, tolerans alt boyutlarından oluşmaktadır. ÇABÖ'nün tamamının ve alt boyutlarının, YIBBT-KF ve KÇSA alt boyutları ile aralarındaki korelasyonlar Tablo 4'de gösterilmektedir.

YIBT-KF ile ÇABÖ'deki belirginlik alt boyutu $(r=.22, p<.01)$, tolerans alt boyutu $(r=.29, p<.01)$, duygudurum değișimi alt boyutu $(r=.28, p<.01)$, yoksunluk alt boyutu $(r=.36, p<.01)$, nüks etme alt boyutu $(r=.27, p<.01)$ ve çatışma alt boyutunun $(r=.29, p<.01)$ pozitif ve istatistiksel olarak anlamlı sonuçlar verdiği görülmektedir.

KÇSA'nın problem-çatışma-nüks alt boyutu ile ÇABÖ'nün belirginlik $(r=.50, p<.01)$, tolerans $(r=.57, p<.01)$, duygudurum değişimi $(r=.48, p<.01)$, yoksunluk $(r=.62, p<.01)$, nüks $(r=$ $.77, p<.01)$ ve çatışma $(r=.59, p<.01)$ alt boyutlarının pozitif ve istatistiksel olarak anlamlı sonuçlar verdiği görülmektedir.

KÇSA'ın düşünce ile meşgul olma alt boyutu ile ÇABÖ'nün belirginlik $(r=.66, p<.01)$, tolerans $(r=.63, p<.01)$, duygudurum değişimi $(r=.51, p<.01)$, yoksunluk $(r=.63, p<.01)$, nüks $(r=$ $.48, p<.01)$ ve çatışma $(r=.45, p<.01)$ alt boyutlarının pozitif ve istatistiksel olarak anlamlı sonuçlar verdiği görülmektedir.

KÇSA'ın duygu düzenleme alt boyutu ile ÇABÖ'nün belirginlik ( $r$ $=.50, p<.01)$, tolerans $(r=.55, p<.01)$, duygudurum değişimi $(\mathrm{r}=.82, \mathrm{p}<.01)$, yoksunluk $(\mathrm{r}=.61, \mathrm{p}<.01)$, nüks $(\mathrm{r}=.47, \mathrm{p}$ $<.01)$ ve çatışma $(r=.41, p<.01)$ alt boyutlarının pozitif ve istatistiksel olarak anlamlı sonuçlar verdiği görülmektedir.

KÇSA'ın geri çekilme alt boyutu ile ÇABÖ'nün belirginlik $(r=.52$, $p<.01)$, tolerans $(r=.54, p<.01)$, duygudurum değişimi $(r=$ $.52, p<.01)$, yoksunluk $(r=.70, p<.01)$, nüks $(r=.52, p<.01)$ ve çatıșma $(r=.47, p<.01)$ alt boyutlarının pozitif ve istatistiksel olarak anlamlı sonuçlar verdiği görülmektedir.

KÇSA'ın tolerans alt boyutu ile ÇABÖ'nün belirginlik $(r=.55, p<$ $.01)$, tolerans $(r=.75, p<.01)$, duygudurum değişimi $(r=.58$, $p<.01)$, yoksunluk $(r=.67, p<.01)$, nüks $(r=.65, p<.01)$ ve çatışma $(r=.53, p<.01)$ alt boyutlarının pozitif ve istatistiksel olarak anlamlı sonuçlar verdiği görülmektedir.

Tablo 2: Çevrimiçi Alıșveriș Bağımlılığı ölçeği alt ölçekleri arası korelasyonlar

\begin{tabular}{|c|c|c|c|c|c|}
\hline Belirginlik ve Tolerans & - & & & & \\
\hline Yoksunluk & $.65^{*}$ & $.62^{* *}$ & - & & \\
\hline Nüks & $.60 * *$ & $.49 * *$ & $.62 * *$ & - & \\
\hline \multicolumn{6}{|l|}{$* * \mathrm{p}<.01$} \\
\hline
\end{tabular}


Tablo 3: Çevrimiçi Alıșveriș Bağımlılığı ölçeği betimsel istatistikler ve güvenirlik analizi

\begin{tabular}{|c|c|c|c|c|c|}
\hline & Ort & $\begin{array}{l}\text { Standart } \\
\text { Sapma }\end{array}$ & $\begin{array}{l}\text { Düzeltilmiș } \\
\text { Madde-Bütün } \\
\text { Korelasyonu }\end{array}$ & $\begin{array}{l}\text { Madde } \\
\text { Silindiğinde } \alpha\end{array}$ & İç Tutarlılık \\
\hline \multicolumn{6}{|l|}{ Belirginlik- Tolerans } \\
\hline $\begin{array}{l}\text { 1. Çevrimiçi alışveriş yapmadığım zamanlarda çevrimiçi } \\
\text { alışveriş hakkında düşünmeyi sürdürüyorum. }\end{array}$ & 2.63 & 1.23 & .64 & .91 & \\
\hline $\begin{array}{l}\text { 2. Çevrimiçi alışverişe nasıl daha fazla zaman veya para } \\
\text { ayıracağımı sık sık düşünürüm. }\end{array}$ & 2.05 & 1.19 & .67 & .91 & \\
\hline 3. Çevrimiçi alışveriș benim hayatım için önemlidir. & 2.73 & 1.19 & .52 & .92 & .86 \\
\hline $\begin{array}{l}\text { 4. Son zamanlarda gittikçe artan bir çevrimiçi alışveriş } \\
\text { yapma isteğim var. }\end{array}$ & 2.96 & 1.34 & .71 & .91 & \\
\hline $\begin{array}{l}\text { 5. Çevrimiçi alışveriş yaparken gittikçe daha çok zaman } \\
\text { harcıyorum. }\end{array}$ & 2.76 & 1.36 & .67 & .91 & \\
\hline $\begin{array}{l}\text { 6. Son zamanlarda sık sık hesapsızca çevrimiçi alışveriş } \\
\text { yapıyorum. }\end{array}$ & 1.89 & 1.16 & .69 & .91 & \\
\hline \multicolumn{6}{|l|}{ Duygudurum Değișimi } \\
\hline $\begin{array}{l}\text { 7. Kötü hissettiğimde çevrimiçi alışveriş yapmak bana iyi } \\
\text { hissettirebilir. }\end{array}$ & 2.71 & 1.40 & .67 & .91 & \\
\hline $\begin{array}{l}\text { 8. Üzgün, endişeli, çaresiz veya huzursuz hissettiğimde } \\
\text { kendimi daha iyi hissetmek için çevrimiçi alışveriş } \\
\text { yaparım. }\end{array}$ & 2.24 & 1.33 & .73 & .91 & .88 \\
\hline $\begin{array}{l}\text { 9. Çevrimiçi alışveriș yapmak gerçek hayattaki sorunları } \\
\text { geçici olarak unutmama yardımcı olabilir. }\end{array}$ & 2.12 & 1.22 & .64 & .91 & \\
\hline \multicolumn{6}{|l|}{ Yoksunluk } \\
\hline $\begin{array}{l}\text { 10. Belirli gerekçelerle çevrimiçi alışveriş yapamadığım } \\
\text { zaman kendimi çökkün ve kaybolmuş hissederim. }\end{array}$ & 1.39 & .78 & .66 & .91 & \\
\hline $\begin{array}{l}\text { 11. Bir süre çevrimiçi alışveriş yapmadan hayat benim için } \\
\text { sıkıcı ve neşesiz olurdu. }\end{array}$ & 1.58 & .93 & .66 & .91 & .78 \\
\hline $\begin{array}{l}\text { 12. Çevrimiçi alışveriș yapmaya kalkıșır ve yapamazsam } \\
\text { kendimi huzursuz ve çökkün hissederim. }\end{array}$ & 1.91 & 1.13 & .64 & .91 & \\
\hline \multicolumn{6}{|l|}{ Nüks Etme } \\
\hline $\begin{array}{l}\text { 13. Çevrimiçi alıșveriş yapmayı azaltmayı ya da } \\
\text { durdurmayı denedim ancak başarısız oldum. }\end{array}$ & 1.46 & .87 & .63 & .91 & \\
\hline $\begin{array}{l}\text { 14. Daha az sıklıkla çevrimiçi alıșveriş yapmaya karar } \\
\text { verdim ama bunu başaramadım. }\end{array}$ & 1.43 & .83 & .65 & .91 & .82 \\
\hline $\begin{array}{l}\text { 15. Çevrimiç̧i alışveriş miktarımı bir süre azaltıp yeniden } \\
\text { başlarsam her defasında daha önce yaptığım sıklıkta } \\
\text { alışveriş yapıyorum. }\end{array}$ & 1.72 & 1.09 & .57 & .91 & \\
\hline \multicolumn{6}{|l|}{ Çatıșma } \\
\hline $\begin{array}{l}\text { 16. İș ya da eğitim konusundaki üretkenliğim çevrimiçi } \\
\text { alışverişin doğrudan sonucu olarak azaldı. }\end{array}$ & 1.39 & .84 & .42 & .92 & \\
\hline 17. Bir defasında çevrimiçi alışveriş için ailemle tartıştım. & 1.64 & 1.19 & .40 & .92 & .40 \\
\hline $\begin{array}{l}\text { 18. Çevrimiçi alışveriş yapmak için ailem ve } \\
\text { arkadaşlarımla zaman geçirmeyi kestim. }\end{array}$ & 1.08 & .35 & .37 & .92 & \\
\hline
\end{tabular}

\section{Tartışma}

Çevrimiç̧i Alışveriş Bağımlılığı Ölçeği (ÇABÖ), orjinali İngilizce dilinde çevrimiçi alışveriş bağımlılığını ölçmek için geliștirilmiş bir ölçüm aracıdır. Bu çalışmada Türkçe diline uyarlanmış olan ÇABÖ'nün, Türk kültüründe geçerli ve güvenilir ölçümler yapmayı sağlayacak bir ölçek olduğu sonucu elde edilmiștir.
Günümüzde pandemiyle birlikte daha da yoğun olarak kullanılan çevrimiçi alışverişin bir sonucu olan çevrimiçi alışveriş bağımlılığı bireyin günlük yaşamı, ekonomik durumu ve sosyal hayatı üzerinde negatif etkilere sahiptir. Çevrimiçi Alışveriş Bağımlılığı Ölçeği, davranışsal bağımlılıkla ilgili önceki araştırmalardan yola çıkarak altı faktörlü bileșen modeli ile (41) her bileșenin 
Tablo 4: ÇABÖ, YIBT-KF ve KÇSA Arasındaki Korelasyonlar

\begin{tabular}{|c|c|c|c|c|c|c|c|}
\hline \multicolumn{8}{|l|}{ ÇАВÖ } \\
\hline ÖlçekAdı & $\begin{array}{l}\text { Alt Faktör } \\
\text { Adı }\end{array}$ & Belirginlik & Tolerans & $\begin{array}{l}\text { Duygudurum } \\
\text { Değișimi }\end{array}$ & Yoksunluk & Nüks & Çatıșma \\
\hline \multirow{5}{*}{ KÇSA } & Problem-Çatışma- Nüks & $.50 * *$ & $.57^{* *}$ & $.48^{* *}$ & $.62^{* *}$ & $.77 * *$ & $.59 * *$ \\
\hline & Düşünce ile Meşgul Olma & $.66 * *$ & $.63 * *$ & $.51 * *$ & $63 * *$ & $48 * *$ & $45^{* *}$ \\
\hline & Duygu Düzenleme & $.50 * *$ & $.55^{* *}$ & $.82 * *$ & $.61 * *$ & $.47 * *$ & $.41 * *$ \\
\hline & Geri Çekilme & $.52^{* *}$ & $.54^{* *}$ & $.52 * *$ & $.70 * *$ & $.52 * *$ & $.47^{* *}$ \\
\hline & Tolerans & $.55^{* *}$ & $.78^{* *}$ & $.58 * *$ & $.67^{* * *}$ & $.65 * *$ & $.53 * *$ \\
\hline YIBT-KF & & $.22 * *$ & $.29 * *$ & $.28 * *$ & $.36^{* *}$ & $.27 * *$ & $.29 * *$ \\
\hline
\end{tabular}

üç maddeyle ölçüldüğü 18 maddelik bir ölçektir ve çevrimiçi alıșveriş bağımlılığını ampirik olarak ölçmek için güvenilir ve teoriye dayalı bir araçtır (10). Bu ölçüm aracının orijinal dili olan İngilizce'den çeviri ve geri çeviri yöntemi kullanılarak (39) Türkçe'ye kazandırılması adına geçerlik ve güvenirlik çalıșması yapılmıştır.

Illgili alanyazında ÇABÖ’nün bașka dillere adapte edildiği çalıșmalara rastlanmamış olup ÇABÖ'nün bașka bir dile adapte edilip geçerlik ve güvenirlik çalıșmasının yapılmış olduğu ilk çalıșmanın bu çalıșma olduğu tespit edilmiștir. Doğrulayıcı faktör analizi ile ölçeğin Türkçe versiyonunun orijinalindeki (10) gibi altı faktörlü bir yapıya sahip olup olmadı̆̆ı test edilmiştir. Doğrulayıcı faktör analizi sonuçlarına göre ÇABÖ'nün Türkçe versiyonunun beș faktörde toplanmış halinin altı faktörlü ÇABÖ orijinal modeline uyumlu olduğu saptanmıștır. Kompulsif Çevrimiçi Satın Alma Ölçeği'nin çevrimiçi alışverişler için Türkçe diline adapte edilmiş olan versiyonunda da 7 faktörlü orijinal ölçekten farklı olarak ölçeğin 5 faktörde toplandığı bulunmuştur (31). Ölçek uyarlaması yapılırken, kültürlerdeki değișimlerden dolayı, dinamik yapı ışı̆̆ında gerekli değişimler söz konusu olmaktadır (42).

Çevrimiçi Alışveriş Bağımlılığı Ölçeği (ÇABÖ)'nin alt ölçekleri arasındaki korelasyonlar incelendiğinde tüm alt ölçeklerin birbirleri ile istatistiksel olarak anlamlı korelasyon gösterdiği bulunmuştur; en güçlü korelasyon Belirginlik ve Tolerans alt ölçekleri arasındayken, en zayıf korelasyon Duygudurum Değişimi ve Belirginlik alt ölçekleri arasındadır. Orijinal çalıșmada da alt ölçekler arasındaki korelasyonlar .48 ile .78 arasında değişmekte olup, tümü istatistiksel olarak .01 düzeyinde anlamlıdır (10).

Çevrimiçi Alışveriş Bağımlılığı Ölçeği'nin zamana karşı değişmezliğinin belirlenmesi için test-tekrar test yöntemi kullanılmıştır. Alanyazına bakıldığında genel olarak .70 ve üzeri güvenirlik katsayısına sahip ölçeklerin güvenilir olarak kabul edildiği görülmektedir $(43,44)$. ÇABÖ'nün .79 olarak bulunan katsayısı ile zamana karşı değişmeyen sonuç veren, güvenilir bir ölçek olduğu söylenebilir. Orijinal çalıșmaya bakıldığında testtekrar test güvenirlik çalışması yapıldığına ve sonuçlarına dair bir veri bulunmadığı görülmektedir (10). Ölçek iç tutarlılık değerleri bağlamında incelendiğinde tüm ölçeğin iç tutarlılık değerinin $\alpha=.92$ olduğu görülmüştür. Bunun yanı sıra ölçeğin alt boyutların Belirginlik-Tolerans alt ölçeği $\alpha=.86$, duygudurum değişimi alt ölçeği $\alpha=.88$, yoksunluk alt ölçeği $\alpha=.78$, nüks etme alt ölçeği $\alpha=.82$ ve çatışma alt ölçeği $\alpha=.40$ olarak iç tutarlılık değerleri göstermektedir. Orijinal çalıșma bu bağlamda incelendiğinde tüm ölçeğin iç tutarlılık değerinin $\alpha=.95$ olduğu, ölçeğin alt boyutlarının iç tutarlılık değerlerinin ise $\alpha=.71$ ve $\alpha$ $=.84$ arasında değișiklik gösteren değerler olduğu görülmüștür (10). Türkçe çalıșmada en düşük iç tutarlılığı çatıșma alt ölçeği .40 ile gösterirken orijinal çalışmada en düșük iç tutarlığı belirginlik alt boyutu .71 ile göstermektedir. Alt ölçeklerin üç maddeden oluştuğu göz önünde bulundurulduğunda bu değerlerin kabul edilebilir düzeyde olduğu söylenebilir (10).

Çevrimiçi Alıșveriș Bağımlılığı Ölçeği'nin yapı geçerliği için KÇSA ve YIBT-KF isimli ölçekler ile aralarındaki korelasyon değerleri temel alınmıștır. Beklendiği gibi ÇABÖ ve KÇSA alt boyutlarının birbiriyle ilişkili olduğu gözlemlenmiștir. KÇSA'nın problemçatışma-nüks alt boyutu ile ÇABÖ'nün nüks alt boyutunun yüksek düzeyde ve anlamlı bir ilișkisi olduğu görülmüștür. Bunun yanı sıra KÇSA'nın düşünce ile meşgul olma alt boyutu ile ÇABÖ'nün belirginlik ve KÇSA'nın duygu düzenleme alt boyutu ile ÇABÖ'nün duygudurum değișimi alt boyutları arasında yine yüksek düzeyde ve anlamlı bir ilişki olduğu görülmektedir. KÇSA'nın geri çekilme alt boyutu ile ÇABÖ'nün yoksunluk alt boyutu arasında da beklendiği gibi anlamlı ve pozitif bir ilișki olduğu görülmektedir. Son olarak KÇSA'ın tolerans alt boyutu ile ÇABÖ’nün tolerans alt boyutu arasında anlamlı bir ilișki olduğu belirlenmiştir. Birbirine yapısal açıdan oldukça yakın olan ölçekler olan ÇABÖ ve KÇSA'nın alt boyutları arasındaki bu ilișki, ÇABÖ’nün yakınsak geçerliğini göstermektedir. Bununla birlikte tek faktörlü bir yapıya sahip olan ve internet bağımlılığını ölçen 
YIBT-KF ile ÇABÖ'nün tüm alt boyutları arasında da pozitif ve anlamlı bir ilișki olduğu görülmüștür. Bu sonuç beklendik bir sonuçtur, her ikisi de çevrimiçi ortama ait olan internet bağımlıı̆̆ı ve çevrimiçi alışveriș bağımlılı̆ı arasında bir ilișki olması oldukça anlaşılabilirdir.

$\mathrm{Bu}$ çalıșmanın sonunda elde edilen verilere bakıldığında Çevrimiçi Alışveriş Bağımlılığı Ölçeği'nin Türkçe versiyonunun geçerli ve güvenilir bir araç olduğu söylenebilir. Daha önce bu konuda yapılan araştırmalarda Türkçe dilinde çevrimiç̧i alıșveriş bağımlılığı üzerine ölçüm yapılabilecek bir araca intiyaç duyulduğu ifade edilmiștir (45). Geçerlik ve güvenirlik çalışması yapılan bu ölçek, bağımlılık alanında çalışmalar yapan psikiyatristler ve psikologlar tarafından ön değerlendirme-son değerlendirme yapmak amacıyla kullanılabilecektir. Bunun yanı sıra teknolojinin insan davranışlarıyla iliş̧kisini inceleyen siber psikoloji alanında yapılacak araştırmalar için önem tașıdığı ve ilgili alanyazına katkı sağlayacağı düşünülmektedir. 18 maddeden olușan ölçeğin cevaplama süresi uzun olmayacağından etkili bir şekilde kullanılabileceği düşünülmektedir.

Çalışmanın örnekleminin yoğun olarak özellikleri benzer olan üniversite öğrencisi genç yetișkinlerden olușması, kadın katılımc sayısının erkek katılımcı sayısına oranının daha yüksek olması, çalıșmanın tasarımının kesitsel olması, verilerin çevrimiçi platform üzerinden toplanmış olması bu çalıșmanın sınırlııkları olarak ele alınabilir. Çevrimiçi ortam üzerinden daha az ciddiyet ile soruların cevaplanmış olabilmesi muhtemeldir; ayrıca katılımcıların öz değerlendirme yapmış olmaları, sosyal istenirlik sebebiyle yanlış sınıflandırma yapmış olmalarına neden olmuş olabilir. Verilerin, çevrimiçi alışverişin yoğun olarak tercih edildiği COVID-19 döneminde toplanmış olması etkili bir faktör olarak kabul edilebilir. Gelecekte yapılacak araştırmalarda daha genellenebilir sonuçlar elde edilebilmesi adına daha heterojen bir örneklemle çalışılarak ölçeğin test edilmesi önerilmektedir.

\section{Kaynaklar}

1. Şeker A. Çevrimiçi alıșveriș yapan tüketici davranışlarına yönelik çevrimiçi bir araştırma. İșletme ve İktisat Çalışmaları Dergisi 2020; 8(2): 11-27.

2. Hsiao MH. Shopping mode choice: Physical store shopping versus e-shopping. Transp Res Part F Traffic Psychol Behav 2009; 45(1): 86-95.

3. TÜiK. Hanehalkı bilișim teknolojileri kullanım araştırması [Basın Bülteni]. Available from https://data.tuik.gov.tr/Bulten/Index?p=Hanehalki-BilisimTeknolojileri-(BT)-Kullanim-Arastirmasi-2021-37437 (Accessed August 2021).

4. TÜBISAD. E-Ticaret 2019 Pazar Büyüklüğü Raporu. Available from http://www.tubisad.org.tr/tr/images/pdf/tubisad_eticaret_2019_pazar_ buyuklugu_raporu.pdf (Accessed May 2021).

5. Nguyen HV, Tran HX, Van Huy L, et al. Online book shopping in Vietnam: The Impact of the COVID-19 pandemic situation. Pub Res Q 2020; May: 1-9.

6. Algür S, Cengiz F. Türk tüketicilere göre online (çevrimiçi) alışverișin riskleri ve yararları. Journal of Yașar University 2011; 6(22): 3666-3680.

7. Akhter SH. Digital divide and purchase intention: Why demographic psychology matters. J Econ Psychol 2003; 24(3): 321-327.
8. Grant JE, Potenza MN, Weinstein A, et al. Introduction to behavioral addictions. Am J Drug Alcohol Abuse 2010; 36(5): 233-241.

9. Rose S, Dhandayudham A. Towards an understanding of Internet-based problem shopping behaviour: The concept of online shopping addiction and its proposed predictors. J Behav Addict 2014; 3(2): 83-89.

10. Zhao H, Tian W, Xin T. The development and validation of the Online Shopping Addiction Scale. Front Psychol 2017; 8: 735.

11. Huang JH, Yang, YC. The relationship between personality traits and online shopping motivations. Soc Behav Pers 2017; 38(5): 673-679.

12. Tsao WC, Chang HR. Exploring the impact of personality traits on online shopping behavior. African Journal of Business Management 2010; 4(9): 1800-1812.

13. Muerser KT, Drake RE, Wallach MA. Dual diagnosis: a review of etiological theories. Addict Behav 1998; 23(6): 717-734.

14. Laconi S, Tricard N, Chabrol H. Differences between specific and generalized problematic Internet uses according to gender, age, time spent online and psychopathological symptoms. Comput Human Behav 2015; 48: 236-244.

15. Pontes HM, Szabo A, Griffiths, MD. The impact of Internet-based specific activities on the perceptions of Internet addiction, quality of life, and excessive usage: A cross-sectional study. Addict Behav Rep 2015; 1: 19-25.

16. Kuss DJ, Griffiths MD, Binder JF. Internet addiction in students: Prevalence and risk factors. Comput Human Behav 2013; 29(3): 959-966.

17. Young KS. Internet addiction: A new clinical phenomenon and its consequences. Am Behav Sci 2004; 48(4): 402-415.

18. Ko CH, Yen JY, Chen CS, et al. Psychiatric comorbidity of Internet addiction in college students: an Interview study. CNS Spectr 2008, 13(02): 147-153.

19. Young KS, Rogers RC. The relationship between depression and internet addiction. Cyberpsychol Behav 1998; 1(1): 25-28.

20. Bernardi S, Pallanti S. Internet addiction: a descriptive clinical study focusing on comorbidities and dissociative symptoms. Compr Psychiatry 2009; 50(6): 510-516.

21. Yellowlees PM, Marks S. Problematic internet use or internet addiction? Comput Human Behav 2007; 23(3): 1447-1453.

22. Griffiths M. Does Internet and computer" addiction" exist? Some case study evidence. Cyberpsychol Behav 2000; 3(2): 211-218.

23. Wölfling K, Beutel ME, Koch A, et al. Comorbid internet addiction in male clients of inpatient addiction rehabilitation centers: psychiatric symptoms and mental comorbidity 2013; 201(11): 934-940.

24. Ridgway NM, Kukar-Kınney M, Monroe KB. An expanded conceptualization and a new measure of compulsive buying. J Consum Res 2008, 35(4): 622639.

25. Trotzke P, Starcke K, Müller A, et al. Pathological buying online as a specific form of internet addiction: a model-based experimental investigation. PLoS ONE 2015; 10(10): e0140296..

26. Weinstein A, Mezig H, Mizrachi S, et al. A study investigating the association between compulsive buying with measures of anxiety and obsessivecompulsive behavior among internet shoppers. Compr Psychiatry 2015; 57: 46-50.

27. Lejoyeux M, Arbaretaz M, McLoughlin M, et al. Impulse control disorders and depression. J Nerv Ment Dis 2002; 190(5): 310-314.

28. Clark M, Calleja K. Shopping addiction: A preliminary investigation among Maltese university students. Addict Res Theory 2008; 16(6): 633-649.

29. Andreassen CS, Griffiths MD, Pallesen S, et al. The Bergen shopping addiction scale: reliability and validity of a brief screening test. Front Psychol 2016; 6: 1374 . 
30. American Psychiatric Association. Diagnostic and Statistical Manual of Mental Disorders, Revised Fourth Edition (DSM-IV-TR). Washington DC: American Psychiatric Association, 2000.

31. Bozdağ Y, Yalçınkaya Alkar Ö. Bergen Alıșveriș Bağımlılığı Ölçeği'nin kompülsif çevrimiçi satın alma davranışına uyarlanması. Bağımlılık Dergisi 2018, 19(2): 23-34.

32. Manchiraju S, Sadachar A, Ridgway JL. The compulsive online shopping scale (COSS): development and validation using panel data. Int J Ment Health Addict 2017; 15(1): 209-223.

33. Christo G, Jones SL, Haylett S, et al. The Shorter PROMIS Questionnaire. Addict Behav 2003; 28(2): 225-248.

34. Laconi S, Tricard N, Chabrol H. Differences between specific and generalized problematic Internet uses according to gender, age, time spent online and psychopathological symptoms? Comput Human Behav 2015; 48: 236-244.

35. Dikbaș GT, Acartürk C, Akyunus M. Psychometric properties of the pathological buying screener: Reliability and validity study. Dusunen Adam 2021; 2(34): 123-133.

36. Müller A, Trotzke P, Mitchell JE, et al. The Pathological Buying Screener: Development and psychometric properties of a new screening instrument for the assessment of pathological buying symptoms. PLoS One 2015; 10(10): e0141094.
37. Young KS. Caught in the Net: How To Recognize The Signs Of İternet Addiction--And A Winning Strategy For Recovery. London: Wiley. 1998.

38. Kutlu M, Savcı M, Demir $\mathrm{Y}$, et al. Young Internet Bağımlılığı Testi Kısa Formunun Türkçe uyarlaması: Üniversite öğrencileri ve ergenlerde geçerlilik ve güvenilirlik çalışması. Anadolu Psikiyatri Derg 2016; 17(1): 69-76.

39. Brislin RW, Brislin RW, Lonner WJ, Thorndike RM. Cross-Cultural Research Methods (Vol. 11). New York: Wiley, 1973.

40. George D, Mallery M. SPSS for Windows Step Buy Step: A Simple Guide and Reference, 17.0 update (10a ed.). Boston: Pearson. 2010.

41. Griffiths, M. Behavioural addiction: an issue for everybody? J Workplace Learn 1996; 8(3): 19-25.

42. Çapık C, Gözüm S, Aksayan S. Intercultural Scale Adaptation Stages, language and culture adaptation: updated guideline. Florence Nightingale J Nurs 2018; 26(3): 199-210

43. Pallant J. SPSS Survival Manual: A Step By Step Guide To Data Analysis Using SPSS for Windows. Australian Copyright. 2005.

44. Büyüköztürk Ș, Kılıç Çakmak E, Akgün ÖE, et al. Bilimsel Araștırma Yöntemleri (21. Baskı). Pegem Akademi Yayınları. 2016.

45. Günüç S, Doğan Keskin A. Çevrimiçi alıșveriș bağımlııı̆ı: Belirtiler, nedenler ve etkiler. Addicta 2016; 3(3): 339-364 
EK- Çevrimiçi Alıșveriș Bağımlılığı Ölçeği (ÇABÖ)

\section{Așağıda yer alan maddelerde belirtilen durumları ne sıklıkta deneyimlediğinizi belirtiniz. Her soru için yalnızca bir cevap ișaretleme hakkınız vardır. Soruların tamamının cevaplanması önemlidir, lütfen durumunuzu en iyi ifade eden seçeneği işaretleyiniz.}

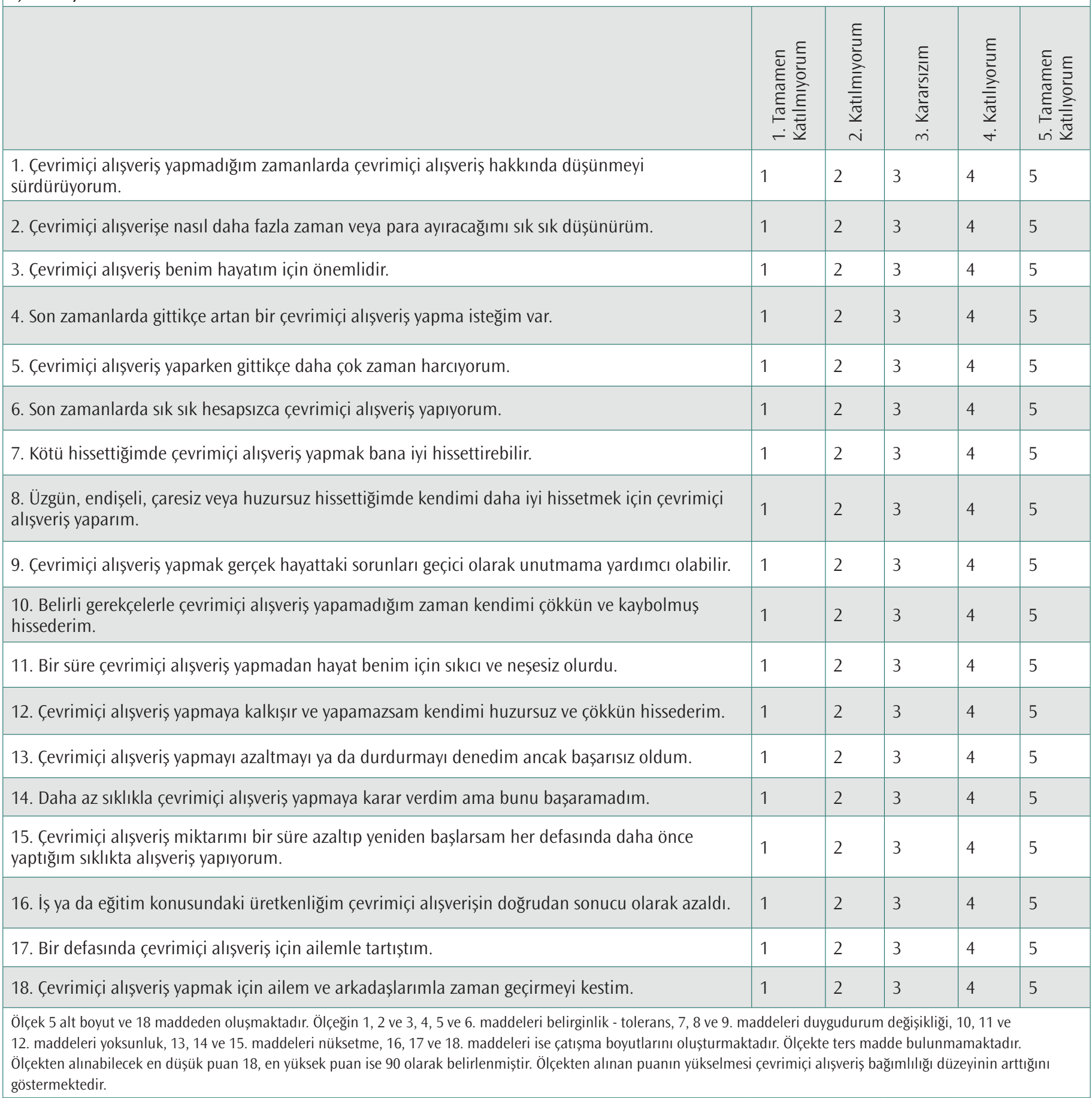

